\title{
Methodical aspects of evaluation of financial architecture of economy
}

\author{
IRYNA HALUSHCHAK \\ Accounting and Auditing Department, Vasyl Stefanyk Precarpathian National University, \\ UKRAINE \\ MYKHAILO KUZHELIEV \\ Department of Finance named after L.L. Taranhul, University of the State Fiscal Service of \\ Ukraine, UKRAINE \\ VIKTOR MELNYK \\ Finance Department, Kyiv National Economic University named after Vadym Hetman, \\ UKRAINE \\ TETIANA MYHOVYCH \\ Department of Finance, Vasyl Stefanyk Precarpathian National University, UKRAINE \\ MAKSYM ZHYTAR \\ Department of Finance named after L.L. Taranhul, University of the State Fiscal Service of \\ Ukraine, UKRAINE
}

\begin{abstract}
The article describes the effectiveness of financial architecture as one of the key aspects of sustainable economic growth and national prosperity, and therefore the methods and models of evaluating financial architecture as an object of study are becoming increasingly relevant. The created methodology is based on the concept of developing an architecture for evaluating financial architecture as the aggregate methods for evaluating the performance of financial systems, whose institutional matrix is financial architecture. The study of methodological aspects of financial architecture valuation substantiates the necessity of applying the concept of financial architecture evaluation, which is based on the basic assumptions for determining: the object of valuation, the typology of financial architecture for the purpose of evaluation, the nature of the indicators used, the interpretation of the results of valuation. The methodological approach to the evaluation of the financial architecture of the national economy is proposed to be based on four main components, such as: financial development, financial institutions, financial markets and financial stability, with an appropriate set of indicators, which will allow to form a comprehensive approach to the evaluation of the national financial architecture have been created.

Key-words: - Financial architecture, Economy, Financial institutions, Institutional environment, Business environment, Financial stability, Banking financial services, Non-banking financial services, Availability of financial resources.
\end{abstract}

Received: October 2, 2020. Revised: March 16, 2020. Accepted: April 3, 2020. Published: April 27, 2020.

\section{Introduction}

Global socio-economic transformations of our time are changing the way we look at the formation and functioning of both financial systems and the financial architecture as a whole. Issues regarding the destructive role of financial mechanisms in social development are increasingly debated $[1 ; 2]$. The effectiveness of financial architecture is seen as one of the key aspects of sustainable economic growth and national well-being. In this regard, methods and models of evaluating financial architecture as a research object are becoming increasingly relevant. 


\section{Data and Methodology}

\subsection{Methodical approach to a comprehensive assessment of the financial architecture of the economy}

A main question regarding the evaluation of financial systems is related to their typology. It is generally accepted in the scientific literature that stock market-oriented financial systems have traditionally been opposed to bank-oriented financial systems. Obvious differences between these types are evident both in the architecture of financial markets and institutions and in the relative importance of financial mechanisms in the economy. The most debatable issues in this case include the benefits of long-term economic growth. However, it has been empirically proven that none of the types of corresponding absolute advantages provides. The rationale for this conclusion is offered within the concept of a general level of financial services, which emphasizes the crucial importance of the effective functioning of the national financial system as a whole, regardless of the predominant role of certain financial mechanisms. In particular, they distinguish between advanced financial systems, which are characterized by significant qualitative and quantitative differences, which, in turn, affect the system of relevant indicators and their grouping.

Developed systems are on average ahead of developing countries in terms of financial depth, provide a higher level of financial penetration, a more diverse list of financial services, characterized by better infrastructure and more. Particular attention should be paid to emerging financial systems (or emerging-market financial systems) that, by some parameters, successfully compete with developed ones. Note, however, that the meaning of the terms "emerging financial systems" and "emerging financial markets" is ambiguous. In some cases, they are identified with any underdeveloped systems, but for the sake of developing a generalized assessment system, this interpretation seems counterproductive. Thus, from our point of view, priority should be given to the level of financial development in the process of developing a methodological approach to the evaluation of financial architecture.
We propose to base four methodical approaches to the assessment of the financial architecture of the national economy with an appropriate set of indicators, which will allow us to form a comprehensive approach to the evaluation of the subject of our research (Fig. 1).

Financial development is defined as a set of influencing factors, policies and institutions involved, whose activities should ensure the effectiveness of financial intermediation and financial markets, as well as broad access to capital and financial resources [3]. According to this definition, financial development indicators are considered through seven groups of indicators:

1) institutional environment - covers financial liberalization of the sector, corporate governance, legal and regulatory issues, contract execution;

2) business environment - takes into account the efficiency of human capital, taxation, infrastructure and costs of doing business;

3) financial stability - covers risk assessment of currency crises, systemic banking crises and sovereign debt crises;

4) financial stability - covers the risk assessment of currency crises, systemic banking crises and sovereign debt crises;;

5) non-bank financial services - Includes IPOs and M\&A Activities, Insurance and Securitization;

6) financial markets - cover foreign exchange and derivatives markets, stock and bond markets;

7) availability of capital and financial resources - assesses commercial and retail access to capital and financial resources.

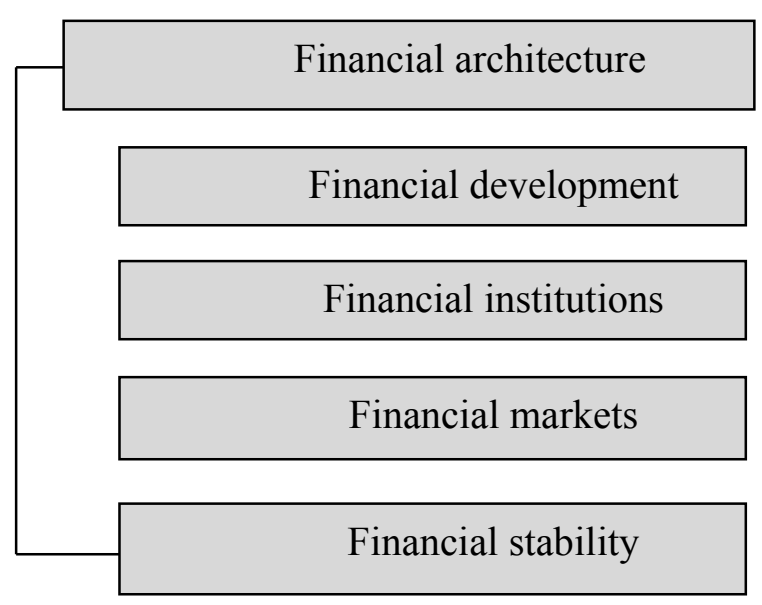


Fig.1. Methodical approach to a comprehensive assessment of the financial architecture of the economy

The degree of depth and effectiveness in providing financial services depends on a number of factors that, in combination with their respective interactions, must be taken into account in order to understand and measure the degree of financial development. Conceptually, various aspects of development can be considered as the seven groups mentioned above, aggregated into three generalizable blocks, in particular:

1) Impact factors, policies and institutions: fundamental characteristics that enable the development of financial intermediation, markets, tools and services;

2) Financial intermediation: the diversity, size, depth and efficiency of financial intermediaries and financial services markets;

3) Access to capital and financial resources: access by individuals and legal entities to various forms of capital and financial services.

\subsection{Indicators for evaluating the financial architecture of the economy}

Summarizing the analysis of the above blocks with the appropriate grouping of financial development indicators in the context of presenting a methodological approach to assessing the financial architecture of the economy, a detailed set of such indicators is presented in Table 1.

Given the specific assessment of the financial architecture of the economy, we believe that the structure and composition of groups of indicators may vary depending on the peculiarities of the configuration of financial architecture, internal and external conditions of its functioning, the effects of the institutional environment, ie it can be dynamic over time, taking into account changes in structural components, interchanging structural components the relationships between them and their respective performance assessments. So, let's determine which indicators can be dynamic and adjustable within seven groups of metrics with related subgroups.
1. Centralization of the economic policy indicator and the index of financial tension on legal and regulatory issues and the stability of the banking system respectively - changes dynamically over time, has no constant values over the analyzed period;

2. Financial Stress Index - does not reflect problems in the banking sector on an ongoing basis, as it focuses mainly on the stressful conditions of the securities markets and exchange rates;

3. As additional variables to the group of indicators of availability of financial resources, to the part of retail access, detailed variables can be included not only the availability of financial services, but also the efficiency of their use:

- an indicator of the number of commercial bank accounts per 100,000 adults per cent of the population (15 years and older) having a current account with an official financial institution;

- indicator of the number of debit cards issued;

- indicator of the share of borrowed capital in the total amount of capital of a financial institution;

4. In the non-banking financial services subgroup, the structure of the insurance indicator may vary in terms of:

- from the level of life insurance to the density of life insurance;

- from life insurance coverage to life insurance density.

5. In the second block "Financial mediation": the indicator "banking financial services" can be supplemented by the following indicators:

- contribution of bank funds to GDP, \%;

- central bank assets in GDP,\%;

GDP, $\%$;

- deposits of the financial system in

- private credit in GDP, $\%$;

- bank deposits in GDP,\%;

- overall profitability;

- bank overheads;

financial markets indicator:

- turnover ratio;

- stock market capitalization in GDP, $\%$;

- the value of the shares listed in GDP, $\%$

- number of registered companies per 10,000 people. 
However, when choosing appropriate indicators it is difficult to draw a clear line between more and less significant factors and indicators. At the same time, the structure and composition of indicators can have a significant impact on the end result. Moreover, complex techniques, including a wide range of indicators, provide the most convenient options for manipulating the final estimates. In our view, the juxtaposition of integral (complex) and simple approaches to the evaluation of individual characteristics of financial architecture is ambiguous, in particular, there are many questions regarding the relevant integral estimates regarding the choice of baseline indicators, the order of their harmonization in the aggregate indicator, and the statistical reliability of the results obtained.

\section{Results}

On the basis of the groups of indicators analyzed, we propose to calculate generalized indicators of financial development as a direct assessment of the financial architecture of the economy in order to further aggregate them and to calculate an integral indicator of the effectiveness of financial architecture.

Since the effectiveness of financial development is characterized by a plurality of groups of indicators with a corresponding set of indicators in each of them, $7(\mathrm{~m}=7)$ are highlighted in our analysis.

The aggregation of features is based on the so-called theory of "additive value", according to which the value of the whole is equal to the sum of the values of its components. If the signs of the set have different units of measurement, then the additive aggregation requires bringing them to one basis, that is, the previous normalization. The vector of primary features $\left[\mathrm{x}_{1}, \mathrm{x}_{2}, \ldots, \mathrm{x}_{\mathrm{m}}\right]$ is replaced by the vector of normalized values $\left[\mathrm{z}_{1}\right.$, $\left.\mathrm{z}_{2}, \ldots, \mathrm{z}_{\mathrm{m}}\right]$.

In practice, various normalization methods are used, which are based on comparing the empirical values of $x_{i}$ with a given value of $a_{i}$.

If $x_{i j}$ - some indicators, $j=1, \ldots, m ; i=1, \ldots, n$, which collectively characterize a particular group of indices, then the integral metric should have the form of a linear convolution:

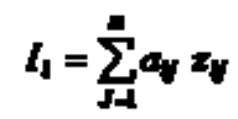

Where $a_{i j-}$ weighting factors that determine the degree of contribution of the $j$-th indicator to the integral indicator of a certain line of activity;

$\mathrm{z}_{\mathrm{ij}}$ - normalized input values $\mathrm{x}_{\mathrm{ij}}$.

This index is equal to 1 when all $\mathrm{x}_{\mathrm{ij}}$ become "best" or optimal, and 0 when all indicators are "worst".

All $\mathrm{a}_{\mathrm{ij}}$ satisfy such conditions as:

$$
\begin{aligned}
& 0 \leq a_{1, j} \leq 1, \\
& \sum_{j} a_{v}=1
\end{aligned}
$$

Each of $z_{i j}$ is normalized, that is $0 \leq z_{i} \leq 1$, moreover $z_{i j}=1$ corresponds to the optimum value, and $z_{i j}=0-$ to the worst. 
Table 1. Indicators for evaluating financial architecture in terms of financial development indicators (Compiled by authors based on materials World Economic Forum)

\begin{tabular}{|l|}
\hline \multicolumn{1}{|c|}{ Business environment } \\
\hline Human capital: \\
- quality of education; \\
- quality of personnel training; \\
- local availability of specialized research and \\
training services; \\
\hline Taxation: \\
- irregular payments at tax collection; \\
- the impact of taxes and subsidies on \\
competition; \\
- marginal tax change; \\
- time of payment of taxes; \\
\hline Infrastructure: \\
- quality of general infrastructure; \\
- quality of power supply; \\
- Internet users; \\
- Broadband subscriptions; \\
- Mobile subscribers \\
\hline Costs of doing business: \\
- the cost of starting a business; \\
- cost of property registration; \\
- cost of closing a business; \\
- time to start a business; \\
- time of property registration; \\
- business closing time \\
\hline \multicolumn{1}{c|}{ Financial stability } \\
\hline Banking system stability: \\
- frequency of banking crises; \\
- financial sustainability indicator; \\
- Aggregate measure of bubbles in the real \\
estate market; \\
- loss of production of national product during \\
banking crises; \\
\hline Currency stability: \\
- change in the real effective exchange rate \\
(REER); \\
- external vulnerability; \\
- current account balance to GDP; \\
- dollarization vulnerability indicator; \\
- external debt to GDP (for developing \\
economies); \\
net international investment position in GDP \\
(for advanced economies); \\
\hline The sovereign debt crisis risk: \\
- sovereign currency rating in \\
currency; \\
\hline
\end{tabular}

- sovereign foreign currency rating;

- Public debt management;

- spread of credit default swap

Financial intermediation

Impact factors, policies and institutions Institutional environment

Financial sector liberalization:

- capital account liberalization;

- commitments to the WTO Agreement on Trade in Services;

- internal liberalization of the financial sector;

Corporative management:

- amount of compensation based on incentives;

- efficiency of work of corporate councils;

- willingness to delegate authority;

- Strength of auditing and reporting standards;

- ethical behavior of firms;

protection of interests of minority shareholders;

Legal and regulatory issues:

- burdening of state regulation;

- regulation of the stock market;

- protection of property rights;

- protection of intellectual property;

- public trust in politicians;

- Corruption Perceptions Index;

- transparency of central bank activity;

Execution of a social contract:

- effectiveness of law-enforcement bodies;

- judicial independence;

- contract term;

- number of procedures for performance of the contract;

- investor protection strength index;

- cost of performance of contracts;

\section{Banking financial services}

Performance Index:

- cumulative profitability indicator;

- bank overheads;

- share of state property in the banking sector;

- bank operating expenses for assets;

- share of inefficient bank loans to the total amount of loans

Size Index:

- share of bank assets in GDP;

- share of central bank assets in GDP;

- deposits of the financial system in GDP;

- part of M2 to GDP;

- share of private loans in GDP;

- share of bank deposits in GDP;

- money market instruments to GDP 


\begin{tabular}{l}
\hline Financial Disclosure: \\
- coverage of the private credit sector; \\
- coverage of the register of public loans \\
\hline \multicolumn{1}{|c|}{ Non-banking financial services } \\
\hline IPO Activity: \\
- IPO market share; \\
- amount of IPO proceeds; \\
- share of world IPOs; \\
\hline Insurance: \\
- penetration of life insurance; \\
- real increase in direct insurance premiums; \\
- life insurance density; \\
- relative value added of insurance to GDP; \\
\hline Securitization: \\
- securitization to GDP; \\
- share in the total number of securitization \\
agreements; \\
\hline M\&A activities: \\
- M\&A market share; \\
- transaction value of M\&A in GDP; \\
- share in the total number of M\&A \\
transactions \\
\hline \multicolumn{1}{|c|}{ Financial markets } \\
\hline Currency markets: \\
- spot currency circulation; \\
- open currency circulation; \\
- currency circulation \\
\hline Derivatives markets: \\
- interest derivatives turnover: forward rate; \\
- interest derivatives turnover: swaps; \\
- currency derivatives circulation: currency \\
- the presence of venture capital; \\
\hline Stock Market Development: \\
- share of stock market capitalization in \\
GDP,\%; \\
- the value of shares traded to GDP \\
\hline Bond Market Development: \\
- market capitalization of private bonds to \\
GDP; \\
- capitalization of government bonds to \\
GDP,\% \\
- Private international bonds to GDP; \\
- government international bonds to GDP; \\
- Issuance of corporate bonds in local currency \\
to GDP \\
\hline
\end{tabular}

- ease of access to credit resources;

- possibility of financing through the local stock market;

- easy access to loans;

- share of foreign direct investment in GDP.

Retail access:

- availability of banking services market;

- number of branches of commercial banks;

- total number of ATMs;

- MFI loan accounts;

- number of loans in financial institutions.

In our case, the complexity of the calculations is that the metrics we choose to measure financial performance are not only diversified, but also divergent with respect to their benchmarks, as some of them have to either increase or have to become values of $100 \%$ or more, and others - on the contrary - acquire minimum values (or approach zero). That is, our $\mathrm{x}_{\mathrm{ij}}$ are financial performance indicators that require a standardization procedure to calculate generalized $\mathrm{x}_{\mathrm{i}}$ indicators $(\mathrm{i}=7)$ to further group them into a single integral financial development performance indicator Ii.

Normalized values of generalized $\mathrm{x}_{\mathrm{i}}$ indicators are obtained in two ways:

- as a product of the normalized indicators that compose it. In this case, it is possible to obtain a zero value of the indicator, if at least one of the indicators was zero, i.e. the efficiency of work in this direction is zero, such an estimate is sufficiently "rigid", but allows to identify the whole problem area;

- as the arithmetic mean of the normalized indicators that make up it, such normalization will avoid zero values of the indicators during the analysis.

We take the weight coefficients $a_{i j}$ equal to each other, that is, we accept all groups of indicators as equal.

Recall that the highest level of efficiency is achieved at value $I_{i}=1$.

With respect to the second and third components of the financial architecture assessment, we believe that preference should be given to quantitative and, above all, statistical indicators that characterize the status of key elements of financial architecture - financial markets and financial institutions [4]. 
The performance of financial institutions is measured by the following indicators:

- share of bank loans to non-financial institutions in GDP (\%) - measures the share of domestic lending to the real sector at the expense of bank deposits as a percentage of GDP;

- proportion of adults (aged 15+ years) who have an account with an official financial institution $(\%$,$) - measures the percentage of$ adults who have an account with a bank, credit union, or other financial institution, including adults who have a debit card;

- bank credit and deposit spread (in percentage points) is a credit rate minus a deposit rate. Credit rate - is the rate charged by banks on private sector loans, and the interest rate on deposit is the rate paid by commercial banks on demand;

- Bank's weighted average Z-account calculated as $[\mathrm{ROA}+$ (equity / assets)] / (standard deviation of ROA).

The performance of financial markets is considered by the following indicators:

- stock market capitalization to GDP (\%) measures the capitalization of all stock markets as a percentage of GDP;

- market capitalization, excluding the top 10 companies, to total market capitalization (\%) measures the ratio of market capitalization outside the top 10 largest companies to total market capitalization;

- the stock market turnover ratio (\%) is the ratio of the total value of the shares traded during the period to the average market capitalization for the respective period. The average market capitalization is calculated as the average at the end of the period for the current and previous periods;

- financial asset price volatility is a 360day standard deviation in earnings from the primary national stock market index.

The fourth component of the evaluation of financial architecture is financial stability, in the context of our study requires definitional and methodological clarifications. Yes, we consider it essential to identify five key principles that should be followed when developing a definition of financial stability for evaluating financial architecture:

- financial stability encompasses various structural components of financial architecture: institutions, markets, infrastructure;

- financial stability implies that financial architecture effectively performs its resource and risk allocation functions, ensuring the proper functioning of all structural components;

- financial stability implies not only the absence of economic crises, but also the ability of financial architecture to limit and offset various imbalances in a timely manner, ie before they harm the architecture itself;

- financial stability should be viewed in terms of its impact on the real economy: if disruptions in the functioning of financial markets or institutions do not pose a threat to the real economy, they should not be regarded as a threat to financial stability;

- financial stability should be understood not as a certain stable state or direction of dynamics to which the financial architecture should return after unbalance, but a defined range or continuum.

In the theoretical and practical plane, the definition of "financial stability" in relation to national financial systems has become most widespread. Thus, G. Shinazi formulates the definition of "financial stability" as follows: "The financial system is in the range of stability when it is capable of improving the productivity of the economy, as well as eliminating financial imbalances that arise endogenously or as a result of significant negative and unpredictable events." [5].

A number of definitions of financial stability, developed by central banks of different countries, are broadly consistent with the general principles behind the construction of their financial systems. In particular, the European Central Bank states: "Financial stability can be defined as a condition in which a financial system that includes financial intermediaries, markets and market infrastructure is able to withstand shocks and eliminate financial imbalances, thereby reducing the likelihood of disruptions in the process. financial intermediation that impedes the effective use of the investment potential of savings » [6].

Summarizing the definition of financial stability and the principles outlined above, we will give our own vision of the concept of "stability of financial architecture" - a state of financial architecture, which ensures the dynamic 
stability of its configuration, the effective functioning of structural components at all levels of the hierarchy with the ability to absorb exogenous absorption. their consequences [7].

On the basis of the structural components of financial architecture, we present financial stability factors. As defined in previous studies [8-11], financial architecture can in the broadest sense be interpreted as a set of the following structural components: state and local finance, household finance, business finance, financial intermediaries, non-profit organizations, financial markets, financial infrastructure . However, only three of the previously listed components, namely financial intermediaries, financial markets and infrastructure component, perform the basic functional load of the financial architecture, such as the allocation of economic resources, risk sharing and payments.

Accordingly, the configuration of a financial architecture is not limited to the three elements mentioned, although the other elements not included in this list cannot be ignored in the financial stability analysis process, since they are closely interrelated. In this regard, in the framework of the study, the stability of the financial architecture will be considered according to the performance evaluation of such structural components that determine the configuration of the financial architecture, namely: stability of the banking and financial sector, stability of financial markets and quality of financial infrastructure, stability of public finances, stability of the business sector, stability of household finances. The internal and external factors of financial stability, as well as the indicators that can be used to quantify them, are presented in Table 2.

Table 2. Indicators for assessing the stability of the structural components of the financial architecture of the economy

\begin{tabular}{|l|l|}
\hline $\begin{array}{l}\text { Structural } \\
\text { components }\end{array}$ & $\begin{array}{l}\text { Indicators for assessing } \\
\text { the stability of a } \\
\text { structural component of a } \\
\text { financial architecture }\end{array}$ \\
\hline $\begin{array}{l}\text { stability of the } \\
\text { banking and } \\
\text { financial sector }\end{array}$ & $\begin{array}{l}\text { The ratio of regulatory } \\
\text { capital to risk-weighted } \\
\text { assets; } \\
\text { Level 1 regulatory capital } \\
\text { to risk-weighted assets; }\end{array}$ \\
\hline
\end{tabular}

\begin{tabular}{|c|c|}
\hline & $\begin{array}{l}\text { The ratio of non-performing } \\
\text { loans excluding capital } \\
\text { reserves; } \\
\text { The ratio of non-performing } \\
\text { loans to total gross loans; } \\
\text { Ratio of loans by economic } \\
\text { sectors to total gross loans; } \\
\text { Rate of return on assets; } \\
\text { Rate of return on capital; } \\
\text { The ratio of interest margin } \\
\text { to gross income; } \\
\text { The ratio of non-interest } \\
\text { expenses to gross income; } \\
\text { Ratio of liquid assets to } \\
\text { total assets; } \\
\text { Ratio of liquid assets to } \\
\text { short-term liabilities; } \\
\text { The ratio of the net open } \\
\text { position in foreign currency } \\
\text { to equity }\end{array}$ \\
\hline $\begin{array}{l}\text { stability of } \\
\text { financial } \\
\text { markets }\end{array}$ & $\begin{array}{l}\text { Average daily turnover } \\
\text { ratio in the securities } \\
\text { market; } \\
\text { The average spread } \\
\text { between supply and } \\
\text { demand rates in the } \\
\text { securities market; } \\
\text { Volatility; } \\
\text { Credit spread }\end{array}$ \\
\hline $\begin{array}{l}\text { quality of } \\
\text { financial } \\
\text { infrastructure }\end{array}$ & $\begin{array}{l}\text { Compliance with } \\
\text { international standards }\end{array}$ \\
\hline $\begin{array}{l}\text { stability of } \\
\text { public finances }\end{array}$ & $\begin{array}{l}\text { The ratio of interest } \\
\text { payments on external debt } \\
\text { to government revenues; } \\
\text { The ratio of public debt to } \\
\text { public revenue; } \\
\text { Government debt to gold } \\
\text { and foreign exchange } \\
\text { reserves; } \\
\text { Government debt to GDP } \\
\text { ratio,\%; } \\
\text { The ratio of external debt to } \\
\text { exports; } \\
\text { Sovereign ratings of } \\
\text { international rating } \\
\text { agencies }\end{array}$ \\
\hline stability of the & Financial leverage \\
\hline
\end{tabular}




\begin{tabular}{|l|l|}
\hline business sector & $\begin{array}{l}\text { Return on equity; } \\
\text { The ratio of profits to debt } \\
\text { service costs; } \\
\text { The ratio of net open } \\
\text { currency position to equity; } \\
\text { The frequency of corporate } \\
\text { defaults }\end{array}$ \\
\hline $\begin{array}{l}\text { stability of } \\
\text { household } \\
\text { finances }\end{array}$ & $\begin{array}{l}\text { Household debt to GDP } \\
\text { ratio; } \\
\text { The ratio of debt service } \\
\text { costs to income. }\end{array}$ \\
\hline
\end{tabular}

Thus, the methodology of integrated assessment of the financial architecture of the economy appeals to the evaluation of the performance of the financial sector and, above all, the financial markets and financial institutions. Assessment of the level of financial development and financial stability is crucial, while the typology of financial architecture by the criterion of prevailing financial mechanisms and the relationships between the structural components of its configuration is not decisive.

\section{Conclusion}

The wide variety of methodological approaches to the evaluation of financial architecture generally boils down to the following basic aspects:

first, the appropriate methodology can be complex or quantitative, focused on the statistical characteristics of financial depth, efficiency, stability, etc.;

second, the outcome of the assessment may be represented by a scorecard or an integral metric.

A comprehensive approach to assessing the financial architecture of an economy involves assessing the basic conditions for its formation and functioning, which usually requires an analysis of the quality of the institutional environment and provides ample scope for manipulation. Therefore, from our point of view, the most promising areas of further research on this issue should be related to the development of quantitative methods for assessing the structural components of the financial architecture by hierarchy, including the justification of the index of financial development on the basis of statistical indicators of the financial sector, financial institutions, financial markets, and financial architecture stability.

\section{References:}

[1] Zhuo Zhang, Jia Wang, Financial Model based on Principle Component Analysis and Support Vector Machine International journal of circuits, systems and signal processing (NAUN), 183-190, Volume 13, 2019.

[2] Xia Li, Optimization of VRP for Single Distribution Center Based on Improved Saving Method

International journal of circuits, systems and signal processing (NAUN), pp.213-221, Volume 13,2019

[3] The Financial Development Report 2012. Geneva, NY: World Economic Forum.

[4] Global Financial Development Report 2017/2018: Bankers without Borders.

[5] Shinasi G. Defining Financial Stability. IMF Working Paper, 2004 URL: http://www.imf.org/external/pubs/ft/wp/2004/wp 04187.pdf (P.8)

[6] European Central Bank. Financial Stability Review, 2010.

[7] Sosnovska O., Zhytar M. Financial architecture as the base of the financial safety of the enterprise. Baltic Journal of Economic Studies, 2018. Vol. 4. № 4. P. 334-340.

[8] Мельник В.М., Бичкова Н.В. Фінансова архітектура національних корпорацій та іiі вплив на ефективність фінансової діяльності: монографія. Тернопіль: Астон, 2012, 244 c.

[9] Kuzheliev M., Rekunenko I., Boldova A., Zhytar M. Modeling of structural and temporal characteristics in the corporate securities market of Ukraine. Investment Management and Financial Innovations. № 2. 2019, 260-269.

[10] Arellano M., Bond S. Sometests of specification for panel data: Monte Carlo evidence and an application to employment equations. Review of Economic Studies, 58 (2), 277-297.

[11] Blundell R., Bond S. Initial conditions and moment restrictions in dynamic panel data models. Journal of Econometrics, 87 (1), 115143. 